University of Nebraska - Lincoln

DigitalCommons@University of Nebraska - Lincoln

USDA Forest Service / UNL Faculty Publications U.S. Department of Agriculture: Forest Service --

National Agroforestry Center

2011

\title{
Invasive Sweetclover (Melilotus alba) Impacts Native Seedling Recruitment Along Floodplains of Interior Alaska
}

\author{
Blaine T. Spellman \\ University of Alaska Fairbanks, blainespellman@gmail.com \\ Tricia L. Wurtz \\ USDA Forest Service
}

Follow this and additional works at: https://digitalcommons.unl.edu/usdafsfacpub

Spellman, Blaine T. and Wurtz, Tricia L., "Invasive Sweetclover (Melilotus alba) Impacts Native Seedling Recruitment Along Floodplains of Interior Alaska" (2011). USDA Forest Service / UNL Faculty

Publications. 258.

https://digitalcommons.unl.edu/usdafsfacpub/258

This Article is brought to you for free and open access by the U.S. Department of Agriculture: Forest Service -National Agroforestry Center at DigitalCommons@University of Nebraska - Lincoln. It has been accepted for inclusion in USDA Forest Service / UNL Faculty Publications by an authorized administrator of DigitalCommons@University of Nebraska - Lincoln. 


\title{
Invasive sweetclover (Melilotus alba) impacts native seedling recruitment along floodplains of interior Alaska
}

\author{
Blaine T. Spellman • Tricia L. Wurtz
}

This article is a U.S. government work, and is not subject to copyright in the United States.

Received: 23 March 2010/Accepted: 21 December 2010/Published online: 6 January 2011

(C) Springer Science+Business Media B.V. 2011

\begin{abstract}
Sweetclover (Melilotus alba) is a nonnative legume that has formed dense and extensive patches along several rivers in Alaska. Our research objective was to determine if sweetclover impacts recruitment of native seedlings in floodplain habitats. To determine if sweetclover impacted recruitment, we conducted a removal experiment along two rivers in interior Alaska. When compared to areas where sweetclover was removed, areas with sweetclover had approximately $50 \%$ greater mortality of native seedlings, 25\% less recruiting species, and a significant reduction in the quantity of light available to seedlings on floodplain surfaces. To determine if sweetclover shading was a mechanism that limited seedling recruitment, we grew eight common earlysuccessional floodplain plant species in a greenhouse under a range of lighting conditions that were representative of shading under sweetclover. We observed that species restricted to the earliest seral stages of floodplain succession experienced greater reductions in biomass than species that persist into later stages of floodplain succession. Shading
\end{abstract}

B. T. Spellman ( $\square)$

University of Alaska Fairbanks School of Natural

Resources and Agricultural Sciences, Fairbanks, AK,

USA

e-mail: blainespellman@gmail.com

T. L. Wurtz

USDA Forest Service, R10 S\&PF, Forest Health

Protection, Fairbanks, AK, USA seedlings in a greenhouse did not lead to mortality during the growing season. However, when seedlings were over-wintered, we observed that greater shading during the growing season can result in higher seedling mortality. Our study indicates sweetclover invasions have created a novel shade environment in early seral floodplain plant communities, which has the potential to alter community composition. To preserve biodiversity and structure of plant communities, sweetclover should be actively managed to prevent its spread onto additional glacial rivers in Alaska.

Keywords Boreal - Competition - Invasion · Non-native species · Recruitment $\cdot$ Riparian

\section{Introduction}

While the number and abundance of non-native plant species in boreal and arctic systems tends to be low compared to other systems, the rate of non-native plant introduction and spread in some high-latitude habitats is accelerating (Carlson and Shephard 2007). Between 1941 and 2006, the number of non-native plants recorded in Alaska increased by $46 \%$ (Carlson and Shephard 2007). Warmer winters (Chapman and Walsh 1993; Serreze et al. 2000), a longer growing season (Myneni et al. 1997), and increased propagule pressure (Conn et al. 2008b) have likely contributed to the greater number of non-native species becoming 
established and thriving in high-latitude ecosystems. While vast expanses of Alaska do not have invasive plant species (AKEPIC 2010), non-native plants have begun to move from human disturbances to form populations in early successional riparian and postfire habitats (Conn et al. 2008a; Villano 2008). Land managers are concerned because, outside of Alaska, invasive species have been shown to dramatically alter biodiversity, ecosystem processes, and the structure of plant communities (Mack et al. 2000; Levine et al. 2003). In particular, early successional communities in interior Alaska are home to a greater number of rare and endemic plant species than midand late-successional habitats (Lipkin and Murray 1997; NatureServe 2010). To address these concerns, we investigated whether an invasive plant impacts floodplain plant communities in Alaska.

Melilotus alba Medik. (Fabaceae) is one of the few non-native species in Alaska to form dense and extensive patches in natural habitats. M. alba, hereafter referred to as sweetclover, has both annual and biennial cultivars, grows $90-200 \mathrm{~cm}$ in height, and can produce up to 350,000 seeds per plant (Turkington et al. 1978). This non-native legume is grown as a crop in much of North America and was sown in Alaska for purposes related to agriculture (Klebesadel 1992) and soil stabilization. Sweetclover is abundant along Alaskan roadsides (AKEPIC 2010; Conn et al. 2008a), a scenario that may have provided the propagules required to invade riparian habitats. Because sweetclover seeds float (Turkington et al. 1978) and can survive greater than 3 years submerged in water (Spellman unpublished data), they can be dispersed long distances in river systems (Wurtz et al. 2006). Dense and extensive patches of this invasive plant are known to exist along glacial rivers in interior, south central, and southeast Alaska (Spellman 2008; Conn et al. 2008a), and have been observed overtopping early-successional plant communities.

Dense patches of sweetclover have the potential to alter native seedling recruitment. Alterations in recruitment can result in changes to the long-term structure of plant communities (Clark et al. 1998; Hubbell et al. 1999; Foster and Tilman 2003) by affecting species richness and abundance (Tilman 1997; Turnbull et al. 2000; Yurkonis et al. 2005). Invasive plants may limit native species' recruitment directly through competition for resources such as space (Brown and Fridley 2003), light (Huenneke and Thomson 1995; Reinhart et al. 2006), and water (Gordon and Rice 2000). Invasive plants can also affect recruitment indirectly through mechanisms such as litter accumulation (Walker and Vitousek 1991), reduced soil disturbance (Thomas 2005), and altered soil microbial communities (Stinson et al. 2006).

As sweetclover overtops early-successional plant communities along glacial rivers in Alaska, shading is a potential mechanism by which sweetclover could impact recruitment of native species. Competition for light has been shown to be a major factor affecting community composition during floodplain succession in boreal Alaska (Walker and Chapin 1986; Chapin et al. 1994, 2006). Early-successional habitats along glacial rivers in Alaska are generally highly disturbed, sparsely vegetated, and open to light (Chapin et al. 2006). Plant communities are composed primarily of short-statured herbaceous plants and seedlings and saplings of shrub and tree species (Van Cleve and Viereck 1981; Chapin et al. 2006). Typically, the recruitment and sparse distribution of native vegetation on these early successional floodplain surfaces are driven by abiotic factors that include sedimentation from floods and timing of seed dispersal relative to high water events (Viereck et al. 1993). As succession progresses and the shrub and tree canopies close, competition becomes a major factor controlling plant distribution, and shade-intolerant species are eliminated (Van Cleve and Viereck 1981; Chapin et al. 2006). Sweetclover has become a source of shade in the earliest seral stages of floodplain succession where native vegetation is adapted to high light availability.

We hypothesized that this novel shade environment limits recruitment of native species and tested our hypothesis using a two-part approach: a field study to determine if sweetclover is impacting native recruitment and a greenhouse study to determine the effect of shade on common early-successional floodplain species. In addition, we ask whether sweetclover has a greater impact on native legumes relative to other functional groups. Research in other ecosystems has suggested that invasive species impact functionally similar species more than functionally dissimilar species (Prieur-Richard et al. 2000; Fargione et al. 2003; Turnbull et al. 2005). 


\section{Methods}

Study sites

The Healy River study site $\left(63^{\circ} 51^{\prime} \mathrm{N}, 148^{\circ} 53^{\prime} \mathrm{W}\right)$ is located $30 \mathrm{~km}$ north of Denali National Park and Preserve. The Nenana River study site $\left(64^{\circ} 13^{\prime} \mathrm{N}\right.$, $149^{\circ} 16^{\prime} \mathrm{W}$ ) is located approximately $50 \mathrm{~km}$ north and downstream of the Healy River study site. Both rivers are part of the Yukon River drainage. Early-successional soils along the Nenana River have low soil nitrogen (0.9 ppm nitrogen) and are sandy with a neutral $\mathrm{pH}(77 \%$ sand, $21 \%$ silt, $2 \%$ clay and a $\mathrm{pH}$ of 7.9) (Conn et al. 2008a). In July of 2006 and 2007, we observed flooding at both sites resulting in sedimentation and disturbance of early-successional soils. Both rivers freeze over in October and remain frozen until late April or early May. Vegetation emerges or leafs out in late May, while senescence occurs during mid September.

We surveyed early-successional plant communities along the Healy River during 2006. We established three floodplain transects perpendicular to the river's course. The transects started at the river's edge and ended $15 \mathrm{~m}$ within closed forest canopies. The transects varied from 160 to $290 \mathrm{~m}$ in length, and were spaced $\geq 500 \mathrm{~m}$ apart. Every $5 \mathrm{~m}$ along each transect, we placed a perpendicular $8 \mathrm{~m} \times 1 \mathrm{~m}$ belt transect. We visually estimated the percent cover of all species within each belt transect. The 15 species with the greatest combined cover along the Healy River study site were (from most to least abundant): sweetclover, Populus balsamifera L., Alnus viridis ssp. crispa Aiton, Salix alaxensis Andersson, Oxytropis campestris L., Chamerion latifolium L., Hedysarum boreale ssp. mackenzii Richardson, Shepherdia canadensis L., Salix niphoclada Rydb., Elaeagnus commutata Bernh., Hedysarum alpinum L., Picea glauca Moench, Rosa acicularis Lindl., Chamerion angustifolium L., and Elymus trachycaulus Link. In 2005, a similar study was conducted along our Nenana River study site (Conn unpublished data); early-successional vegetation was similar on both river study sites.

While sweetclover was among the most abundant species at both our study sites, this non-native species occupied only 8 and $3 \%$ of the early-successional surfaces along the lengths of the Healy and Nenana Rivers (Spellman 2008; Conn unpublished data).
Large portions of floodplain surfaces at our study sites were devoid of vegetation. In our removal experiment, we studied recruitment in dense patches of sweetclover that represented the worst-case for invasion on both rivers.

Sweetclover removal experiment

During 2006 and 2007, we conducted a removal experiment along both the Healy and Nenana Rivers to determine whether sweetclover was impacting native recruitment. A randomized complete block design with 12 replicates was used for each year and site combination. Each of these 48 blocks were established in a sweetclover patch that was $\geq 5 \mathrm{~m} \times 5 \mathrm{~m}$ in area, had 50-90\% sweetclover cover, and was a minimum of $50 \mathrm{~m}$ from other blocks. Each block had three $2 \mathrm{~m} \times 1 \mathrm{~m}$ plots, which we randomly assigned one of three treatments. One plot had all vegetation removed (veg-), leaving bare ground. The veg- treatment was used to determine native recruitment in the absence of influences from other vegetation. One plot had all sweetclover removed ( $\mathrm{sc}-$ ), leaving only native vegetation. The $\mathrm{sc}-$ treatment was used to examine the effects of native vegetation on native recruitment. The remaining plot had both native vegetation and sweetclover present $(\mathrm{sc}+)$. The $\mathrm{sc}+$ treatment was used to examine the effects of sweetclover on native recruitment. Half of the $\mathrm{sc}+$ plots were dominated by second-year sweetclover and the other half dominated by first-year sweetclover plants. As we did not find any statistical differences between recruitment or light availability in these plots (Spellman 2008), we combined data from all $\mathrm{sc}+$ plots.

For each year, removal treatments were applied in both June and July. Plants were clipped at the soil surface and care was taken to minimize soil disturbance. A 0.5-m-wide buffer was created along the perimeter of all treatment plots from which sweetclover was removed. The buffer prevented sweetclover growing outside experimental plots from shading or influencing recruitment in plots.

In experimental plots, we determined the survival and categorized the functional group of non-sweetclover seedlings. Before we conducted experimental manipulation, we removed all non-sweetclover seedlings from plots. Thus, at the beginning of the experiment, each plot had an equal number of potential recruits and differences in seed bank and 
seed rain among plots were controlled through randomization of treatments. To track the survival and count the number of emerging native seedlings in each plot, we marked seedlings with toothpicks during June, July, and August. In September, we determined the proportion of non-sweetclover seedlings that survived in each experimental plot. To address whether sweetclover had a disproportionate impact on the recruitment of native legumes, in September 2007, we identified each surviving recruit to genus or species and categorized them by the following functional groupings: trees and shrubs, graminoids, non-legume forbs, and legumes. Recruits of one non-native species was identified in the experiment but had low abundances in the experimental plots (i.e. three seedlings of Elymus sibiricus; Table 3).

To determine whether treatments affected the quantity of light available to native seedlings, in August 2007, we measured photosynthetically active radiation (PAR) in each plot with a Li-190 quantum sensor (Li-Cor, Lincoln, Nebraska). In the summer of 2007 , eight blocks were destroyed by a flood along the Healy River, and data from these blocks were removed from all analyses.

\section{Sweetclover shade determination}

Along the Healy River in July 2006, we measured PAR in 72 unmanipulated sweetclover patches to determine the relationship between the percent cover of sweetclover and light reduction at the soil surface. We visually estimated sweetclover cover within a $1 \mathrm{~m} \times 1 \mathrm{~m}$ quadrat and then measured the quantity of PAR with a light sensor. We placed the light sensor parallel to the ground at the center of the quadrat and recorded 15-second-averaged PAR values $\left(\mu \mathrm{mol} \mathrm{m} \mathrm{m}^{-2} \mathrm{~s}^{-1}\right)$ at the floodplain surface and above the sweetclover canopy. We determined sweetclover shade values with the following equation: [1- (PAR below sweetclover/PAR above sweetclover) ${ }^{*} 100$.

Greenhouse shade experiment

During 2006 and 2007, we conducted a greenhouse experiment to determine if shading is a mechanism by which sweetclover could impact the recruitment of early-successional floodplain plants. During the growing season of 2006, we grew two native legumes (Hedysarum alpinum and Hedysarum boreale ssp. mackenzii), a native forb (Chamerion latifolium), and two native shrubs (Salix alaxensis and Alnus incana spp. tenuifolia Nutt). During the growing season of 2007, we grew two native legumes $(H$. alpinum and Oxytropis campestris), a native prostrate shrub (Dryas drummondii Richardson), and a native tree (Populus balsamifera). We grew $H$. alpinum both years to determine if conditions in the greenhouse were similar across years. H. alpinum, H. mackenzii, $C$. latifolium, $S$. alaxensis, $O$. campestris, and $P$. balsamifera were among the 15 most abundant plant species at the Healy River study site. A. tenuifolia and the previously mentioned species were among the 15 most common plant species along the Nenana River study site (Conn unpublished data). While D. drummondii did not occur at either study site, we observed this species growing in dense patches of sweetclover along the Matanuska River of south-central Alaska.

We used five shade treatments to simulate light conditions that occur under different sweetclover densities. We created the five shade treatments using wooden frames $(1 \mathrm{~m} \times 0.5 \mathrm{~m} \times 0.75 \mathrm{~m})$ covered in different mesh densities of green shadecloth: high shade (84 \pm 0.3 percent obstruction of ambient PAR; mean $\pm 1 \mathrm{SE}$ ), medium-high shade (75 \pm 0.3 percent obstruction of ambient PAR), medium shade (62 \pm 0.3 percent obstruction of ambient PAR), medium-low shade $(40 \pm 0.3$ percent obstruction of ambient PAR), and a control frame with no shadecloth. It is important to note that a portion of ambient PAR was obstructed by the greenhouse glass itself. The twin-wall polycarbonate that covers the glass panels of the greenhouse are reported to transmit $80 \%$ of clear light. From July 11 to September 11, 2007, PAR was continuously measured from sensors on top of the greenhouse and noon values ranged from 42.2 to $1,128.7 \mu \mathrm{mol} \mathrm{m} \mathrm{m}^{-2} \mathrm{~s}^{-1}$. While we likely captured a range of lighting conditions that can occur under sweetclover in the field, the shading treatments we used are not precisely comparable to light values under sweetclover in floodplain environments.

In May of 2006 and 2007, seeds of eight test species were sown in containers and seedlings grown in a greenhouse for 3 months. We filled containers ( $3 \mathrm{~cm}$ diameter $\times 17.5 \mathrm{~cm}$ deep, shaped like a cone) with soils from the Nenana River floodplain. We presumed that this substrate had Frankia and 
Rhizobia sp., which are necessary for the inoculation of N-fixing A. tenuifolia and native legumes. This assumption was confirmed at harvest, when roots of A. tenuifolia and each native legume were found to have $\mathrm{N}$-fixing nodules. Seedlings were allowed to grow for 2 weeks in the greenhouse before the shade treatments were applied. Each shade treatment had three replicate shading structures. We placed five seedlings of each species under each frame. No supplemental light was provided. Seedlings were watered when the soil in the containers appeared dry. Every third watering, we applied fertilizer dissolved at a ratio of 1:13:50 ppm of $\mathrm{N}: \mathrm{P}: \mathrm{K}$, an amount representative of early-successional floodplains soils invaded by sweetclover in Alaska (Conn et al. 2008a). We harvested shoots and roots of all seedlings and dried them at $70^{\circ} \mathrm{C}$ for 2 weeks. Measured variables were total biomass, root-to-shoot biomass ratio, and growing season survival.

To examine the relationship between shade during the growing season and over-wintering mortality, we grew up to 15 additional seedlings of A. tenuifolia, $S$. alaxensis, $C$. latifolium, and $H$. alpinum under each shade treatment during 2006. In late September, we placed plants outdoors in an uncovered raised bed that was filled with Nenana River sediment. As we did not collect soil temperature data, soil conditions experienced by overwintering seedlings in the raised bed are not comparable to field conditions. After snowmelt in May of 2007, we determined survival of seedlings that had been over-wintered.

\section{Statistical analyses}

We conducted all statistical analyses with SAS 9.1 (SAS Institute, Inc. 1999, Cary, North Carolina). In the removal experiment, we first determined if the presence of sweetclover altered the recruitment of native seedlings. A four-factor analysis of variance (ANOVA) model (Proc GLM) was used with fixed factors being block, year, site, and treatment. Blocks were nested within the year and site factors. To meet model assumptions of normality and homogeneity of variance, proportional data were arcsin transformed. Second, we used a one-way ANOVA (Proc GLM) to determine if removal treatments caused differences in the quantity of PAR available to seedlings on floodplain surfaces. For both analyses, when significant differences existed among factors $(\alpha=0.05)$, we used pair-wise Tukey tests to determine differences among factor levels. Finally, we used Kruskal-Wallis tests to determine if treatments caused differences $(\alpha=0.05)$ in the abundance of seedlings within our four functional groups. We chose this non-parametric test because transforming our data, which had many zeroes, did not result in parametric model assumptions of normality and equal variance.

We used linear regression to determine the relationship between sweetclover cover and shading measured along the Healy River floodplain. To determine the relationship between shading and seedling growth in the greenhouse, we used one-way ANOVA models (Proc GLM) and pair-wise Tukey tests ( $\alpha=0.05$ ) to determine differences among treatments. To meet model assumptions of normality and constant variance, total biomass data for $H$. mackenzii was rank transformed and data for all other species was $\log$ transformed. To meet model assumptions, root-toshoot data for D. drummondii was not transformed and all other test species were rank transformed. To determine whether shade treatments increased season or overwintering seedling mortality, we used Fisher's Exact Test and pairwise $z$ tests $(\alpha=0.05)$.

\section{Results}

Sweetclover removal experiment

Native seedlings growing in plots with sweetclover exhibited significant reductions in survival when compared to plots with native vegetation or no vegetation. Across study years and floodplain study sites, the removal treatments had significant effects on the recruitment of native species (Table 1). Approximately half as many native seedlings survived the $\mathrm{sc}+$ treatment when compared to either the veg - or sc - treatments (Fig. 1). Recruitment in the veg - and sc- treatments did not differ (Fig. 1), suggesting the presence of native vegetation did not adversely affect native seedling recruitment.

PAR available to recruits in plots with sweetclover was significantly lower than plots with native vegetation or no vegetation. The removal treatment had significant effects on the PAR available to native seedlings $\left(F_{2,45}=51.45, P<0.0001\right)$. Mean PAR available to seedlings in the sc+ treatment $\left(529 \mu \mathrm{mol} \mathrm{m} \mathrm{m}^{-2} \mathrm{~s}^{-1}\right.$ ) was significantly less then mean 
Table 1 ANOVA for proportion of native seedlings that survived the sweetclover removal treatments. Data were collected during 2006 and 2007

\begin{tabular}{lrrr}
\hline Source & df & \multicolumn{1}{l}{$F$} & \multicolumn{1}{l}{$P$} \\
\hline Block(Year*Site) & 36 & 1.82 & 0.0160 \\
Year & 1 & 69.83 & $<0.0001$ \\
Site & 1 & 9.72 & 0.0026 \\
Year*site & 1 & 10.95 & 0.0015 \\
Treatment & 2 & 10.38 & 0.0001 \\
Year*treatment & 2 & 0.04 & 0.9627 \\
Site*treatment & 2 & 0.21 & 0.8150 \\
Year*site*treatment & 2 & 2.33 & 0.1045 \\
Error & 72 & & \\
\hline
\end{tabular}

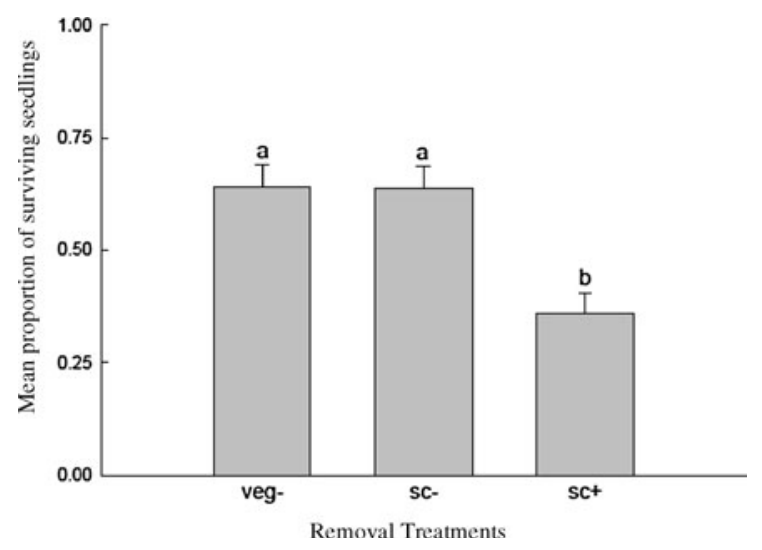

Fig. 1 Mean proportion of native seedlings per plot that survived one growing season. Veg- refers to plots without vegetation, sc- refers to plots with native vegetation and without sweetclover, and sc+ refers to plots with native vegetation and sweetclover. Data are least-square means and bars indicate standard errors. Different letters indicate treatment means differed significantly $(P<0.05)$

PAR available to seedlings in either the veg- or $\mathrm{sc}-$ treatments $\left(1,053\right.$ vs. $1,000 \mu \mathrm{mol} \mathrm{m} \mathrm{m}^{-2} \mathrm{~s}^{-1}$; Tukey Test, $P<0.0001)$. The quantity of PAR in the veg- and sc- treatments did not differ $(P=0.78)$, suggesting native vegetation did not have the same effect. The sparse distribution and short stature of mature native vegetation along our study sites likely contributed to no observed differences in PAR in veg- and sc- plots.

While negatively impacting overall recruitment, the presence of sweetclover did not affect legumes more than other functional groups. Across all functional groups, recruitment within plots was highly variable, which was likely a result of sparse native
Table 2 Mean number of recruits per plot that survived in each functional group during the sweetclover removal experiment. Data were collected during 2007. Standard errors are in parentheses. Veg- refers to plots without vegetation, $s c-$ refers to plots with native vegetation and without sweetclover, and $s c+$ refers to plots with native vegetation and sweetclover

\begin{tabular}{lrlrll}
\hline Treatment & $n$ & \multicolumn{4}{l}{ Functional groups } \\
\cline { 3 - 6 } & & $\begin{array}{l}\text { Trees and } \\
\text { shrubs }\end{array}$ & Graminoids & Forbs & Legumes \\
\hline Veg- & 16 & $2.6(2.5)$ & $2.5(1.1)$ & $15.6(7.5)$ & $1.6(1.0)$ \\
$\mathrm{sc}-$ & 16 & $6.3(6.1)$ & $16.1(6.9)$ & $10.3(4.2)$ & $2.8(2.0)$ \\
$\mathrm{sc}+$ & 16 & $0.5(0.3)$ & $8.1(2.6)$ & $7.8(2.3)$ & $1.7(1.0)$ \\
\hline
\end{tabular}

vegetation in these early successional habitats. For instance, 32 of the total 48 plots in the experiment had no legume recruits. The presence or absence of sweetclover did not affect seedling recruitment for trees and shrubs $\left(X^{2}(2 \mathrm{df})=1.77, P=0.41\right)$, forbs $\left(X^{2}(2 \mathrm{df})=0.17, \quad P=0.92\right)$, or legumes $\left(X^{2}(2 \mathrm{df})=0.77, P=0.68\right)$ (Table 2). A marginal affect was observed in graminoid recruitment $\left(X^{2}(2 \mathrm{df})=5.10, P=0.07\right)$, where the fewest number of surviving seedlings occurred in veg- plots and the greatest number of surviving seedlings occurred in sc- plots (Table 2). When compared to the sc-plots, there was a six-fold decrease in recruitment of the graminoid Festuca rubra in sc+ plots (Table 3). We found 16 taxa recruiting in sc-plots and 12 taxa in $\mathrm{sc}+$ plots representing a $25 \%$ loss in recruit richness (Table 3).

\section{Sweetclover shade determination}

In the 72 patches used to determine sweetclover shading, sweetclover ranged from 1 to $95 \%$ of total estimated cover. Sweetclover cover was positively related with the amount of obstructed PAR $\left(R^{2}=0.88\right.$, $P<0.001, Y=1.03 x+2.72)$. The regression parameter estimate indicates an approximate 1:1 ratio between increases in sweetclover cover and shading. PAR values below the sweetclover canopy ranged from 53.3 to $742.5 \mu \mathrm{mol} \mathrm{m} \mathrm{m}^{-2} \mathrm{~s}^{-1}$.

Greenhouse shading experiment

Shade treatments in the greenhouse experiment obstructed $9-85 \%$ of PAR entering the greenhouse, which fits within the range of lighting conditions 
Table 3 Mean number of recruits per plot that survived in each taxon during the sweetclover removal experiment. Data were collected during 2007. Standard errors are in parentheses. Veg- refers to plots without vegetation, $s c-$ refers to plots with native vegetation and without sweetclover, and $s c+$ refers to plots with native vegetation and sweetclover

\begin{tabular}{|c|c|c|c|c|}
\hline \multirow[t]{2}{*}{ Functional groups } & \multirow[t]{2}{*}{ Taxon } & \multicolumn{3}{|c|}{ Removal treatments } \\
\hline & & Veg- & $\mathrm{sc}-$ & $\mathrm{sc}+$ \\
\hline \multirow[t]{3}{*}{ Tree/shrub } & Populus balsamifera & $0.1(0.1)$ & $0.6(0.5)$ & $0.2(0.1)$ \\
\hline & Alnus sinuata & $0.1(0.1)$ & $0.0(0.0)$ & $0.0(0.0)$ \\
\hline & Salix sp. & $2.4(2.4)$ & $5.7(5.6)$ & $0.3(0.2)$ \\
\hline \multirow[t]{4}{*}{ Graminoid } & Hordeum jubatum & $0.0(0.0)$ & $0.2(0.2)$ & $0.0(0.0)$ \\
\hline & Elymus sibiricus & $0.0(0.0)$ & $0.1(0.1)$ & $0.1(0.1)$ \\
\hline & Elymus trachycaulus & $1.7(0.7)$ & $2.6(1.8)$ & $6.1(2.6)$ \\
\hline & Festuca rubra & $0.8(0.4)$ & $13.2(6.6)$ & $1.9(0.7)$ \\
\hline \multirow[t]{7}{*}{ Forb } & Crepis elegans & $13.7(6.9)$ & $7.9(4.4)$ & $6.3(2.4)$ \\
\hline & Chamerion latifolium & $0.0(0.0)$ & $0.1(0.1)$ & $0.1(0.1)$ \\
\hline & Achillea millefolium & $0.3(0.2)$ & $0.1(0.1)$ & $0.1(0.1)$ \\
\hline & Aster sibiricus & $0.2(0.1)$ & $0.3(0.2)$ & $0.3(0.2)$ \\
\hline & Artemisia tillesii & $0.1(0.1)$ & $0.1(0.1)$ & 0 \\
\hline & Antennaria sp. & $1.3(1.0)$ & $1.8(1.2)$ & $1.1(0.6)$ \\
\hline & Erigeron sp. & $0.1(0.1)$ & $0.1(0.1)$ & $0.0(0.0)$ \\
\hline \multirow[t]{3}{*}{ Legume } & Hedysarum alpinum & $0.4(0.2)$ & $0.6(0.3)$ & $0.4(0.3)$ \\
\hline & Hedysarum boreal spp. mackenzii & $0.6(0.4)$ & $2.1(1.8)$ & $1.3(1.0)$ \\
\hline & Oxytropis campestris & $0.6(0.6)$ & $0.2(0.1)$ & 0 \\
\hline Totals & & $22.3(0.6)$ & $35.6(11.0)$ & $18.1(3.3)$ \\
\hline
\end{tabular}

under sweetclover on the Healy River floodplain. H. alpinum had similar growth and survival responses during both years of the shade experiment (Fig. 2). These findings suggest that greenhouse conditions were similar each year and, subsequently, that data for all species are comparable between years.

As shading increased, production of biomass decreased for each native plant species (Table 4; Fig. 2). For instance, H. mackenzii grown under the high shade treatment had $89 \%$ less biomass than when it was grown under control conditions. With the exception of A. tenuifolia, differences also existed among shade treatments and root-to-shoot ratio of each native species (Table 4). For all affected species, increased shading led to biomass allocation that was skewed towards shoot production (Fig. 2).

The level of shading that caused significant declines in biomass differed among native species. Neither A. tenuifolia nor $P$. balsamifera showed differences in biomass between the control and medium-high shade treatments (Fig. 3), suggesting both species were tolerant of low quantities of PAR. In contrast, when compared to the control, all other test species had significantly less biomass when grown under the medium-high shade treatment
(Fig. 3); the reduction in total biomass exceeded $60 \%$ for $H$. alpinum, H. mackenzii, S. alaxensis, and $O$. campestris. These results indicate that $A$. tenuifolia and P. balsamifera will have greater tolerances to sweetclover shading than other test species.

There was no relationship between levels of shade and seedling survival during the growing season for all species (Fisher's Exact Test, $P>0.15$ ) except H. mackenzii (Fisher's Exact Test, $P=0.001$ ). For H. mackenzii, only seedlings grown in the control treatment died (33\% mortality), which might have resulted from water stress. H. mackenzii responded positively to high quantities of light, as harvested seedlings grown in the control treatment achieved maximum biomass in the experiment (Fig. 2).

Increased levels of shade during the growing season led to higher over-wintering mortality of $S$. alaxensis and A. tenuifolia (Fig. 4). No statistical relationship existed between shade levels and over-wintering mortality of $H$. alpinum or C. latifolium (Fig. 4). However, C. latifolium survived only when grown under the control, medium-low, and medium shade treatments (Fig. 4), which indicates overwintering survival of this species may also depend on the level of shade during the growing season. 
H. alpinum
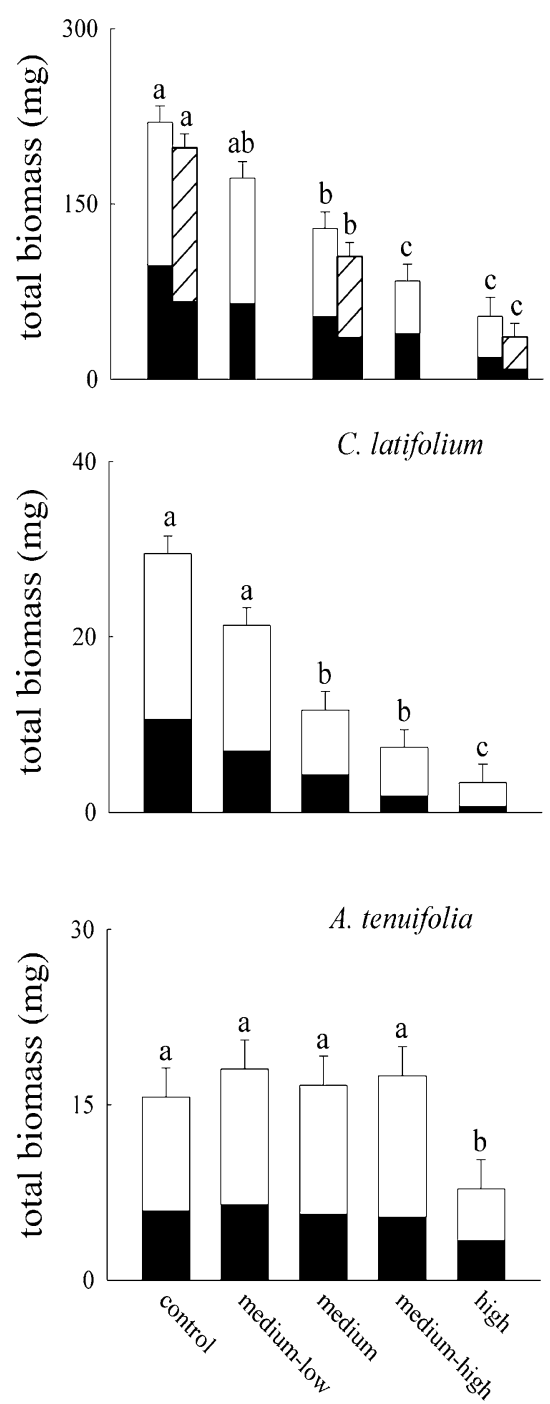

H. mackenzii

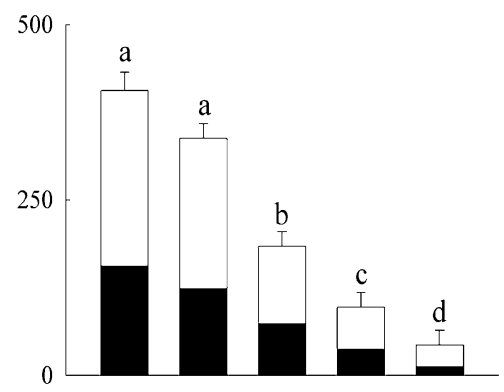

D. drumondii



P. balsamifera

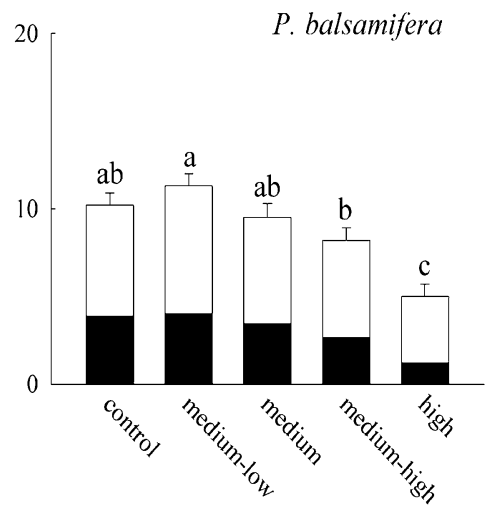

Shade Treatments

U. campestris

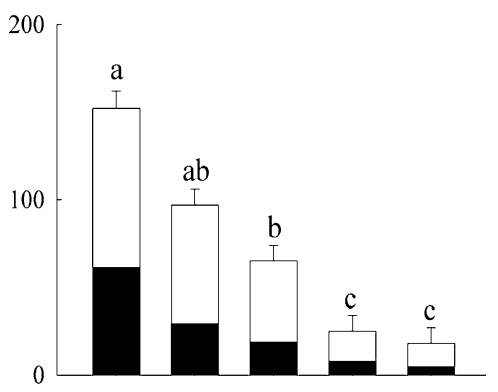

S. alaxensis

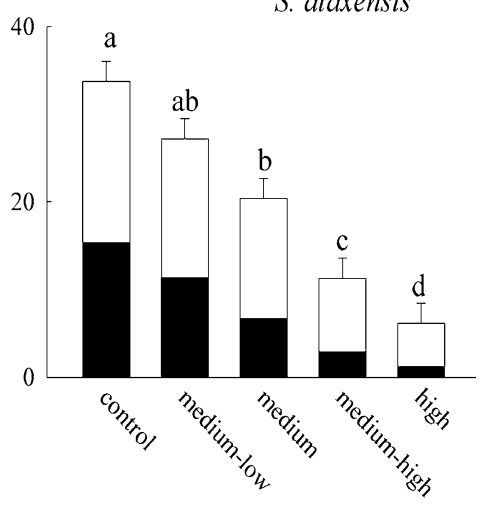

Fig. 2 Mean root, shoot, and total biomass of native species grown under five levels of shading. Bars indicate standard errors for total biomass. For H. alpinum, bars without hatching were grown during 2006, while bars with hatching were grown

\section{Discussion}

Sweetclover impacts on native plant recruitment

Our study demonstrated that dense patches of sweetclover limit recruitment of native species within the earliest seral stages of glacial floodplain succession in interior Alaska. Typically, the recruitment and sparse during 2007. Means for $H$. alpinum were not compared across years. Different letters indicate treatment means for total biomass differed significantly between shade treatments $(P<0.05)$

distribution of native vegetation on these early successional floodplain surfaces are driven by abiotic factors (Viereck et al. 1993). Biotic factors, such as competition, only start to influence recruitment patterns after approximately 20 years when the tree and shrub canopy begin to close (Chapin et al. 2006). Our study suggests that dense patches of sweetclover present new biotic interactions that influence native 
Table 4 ANOVA $F$ values of variables collected for native species grown in a greenhouse shade experiment. The corresponding numerator and denominator degrees of freedom are in parentheses. Asterisks indicate significant $P$ values: (* $P<0.05, * * P<0.01$, *** $P<0.0001)$

\begin{tabular}{|c|c|c|}
\hline \multirow[t]{2}{*}{ Species } & \multicolumn{2}{|c|}{ Growth parameters } \\
\hline & Final biomass & Root:shoot ratio \\
\hline H. alpinum 2006 & $23.8_{(4,68)} * * *$ & $6.0_{(4,68)} * *$ \\
\hline H. alpinum 2007 & $43.9_{(2,41)} * * *$ & $10.4_{(2,41)} * *$ \\
\hline H. mackenzii & $76.2_{(4,65)}$ *** & $6.1_{(4,65)} * *$ \\
\hline O. campestris & $32.4_{(4,68)} * * *$ & $6.5_{(4,68)} * *$ \\
\hline C. latifolium & $39.4_{(4,68)} * * *$ & $3 \cdot 2_{(4,68)} *$ \\
\hline D. drummondii & $6.7_{(4,69)} * * *$ & $27.4_{(4,69)} * * *$ \\
\hline S. alaxensis & $34 \cdot 9_{(4,70)} * * *$ & $20.0_{(4,70)} * * *$ \\
\hline A. tenuifolia & $4.8_{(4,70)} * *$ & $2.4_{(4,70)}$ \\
\hline P. balsamifera & $16.7_{(4,66)}$ *** & $6.6_{(4,66)} * *$ \\
\hline
\end{tabular}

vegetation recruitment in early successional glacial floodplain habitats of interior Alaska.

While sweetclover did decrease native plant recruitment overall, sweetclover competition did not impact recruitment of native legumes more than other functional groups. These results contrast with other studies that have shown strong competitive interactions among species that share functional groupings
(Prieur-Richard et al. 2000; Fargione et al. 2003; Turnbull et al. 2005). The native legumes in our removal experiment may have a high-tolerance to sweetclover competition. In a competition experiment, sweetclover seedlings grown at high densities did not competitively suppress or kill seedlings of two native legumes that are common at both our study sites (i.e. Hedysarum alpinum or Oxytropis campestris; Spellman 2008). While we did not find treatment effects for legumes, we did find that the presence of sweetclover reduced the recruitment of graminoids more than other functional groups. This suggests that sweetclover does impact functional groups and species differentially, but that our limited sample size and the small number of propagules entering plots likely contributed to the difficulty in finding statistically significant differences. In the future, native seed addition experiments (Turnbull et al. 2000) might better determine the impact sweetclover has on specific functional groups and species.

Shading as a mechanism underlying sweetclover impacts

Shading is a mechanism by which dense patches of sweetclover can stress and kill native plants in early-

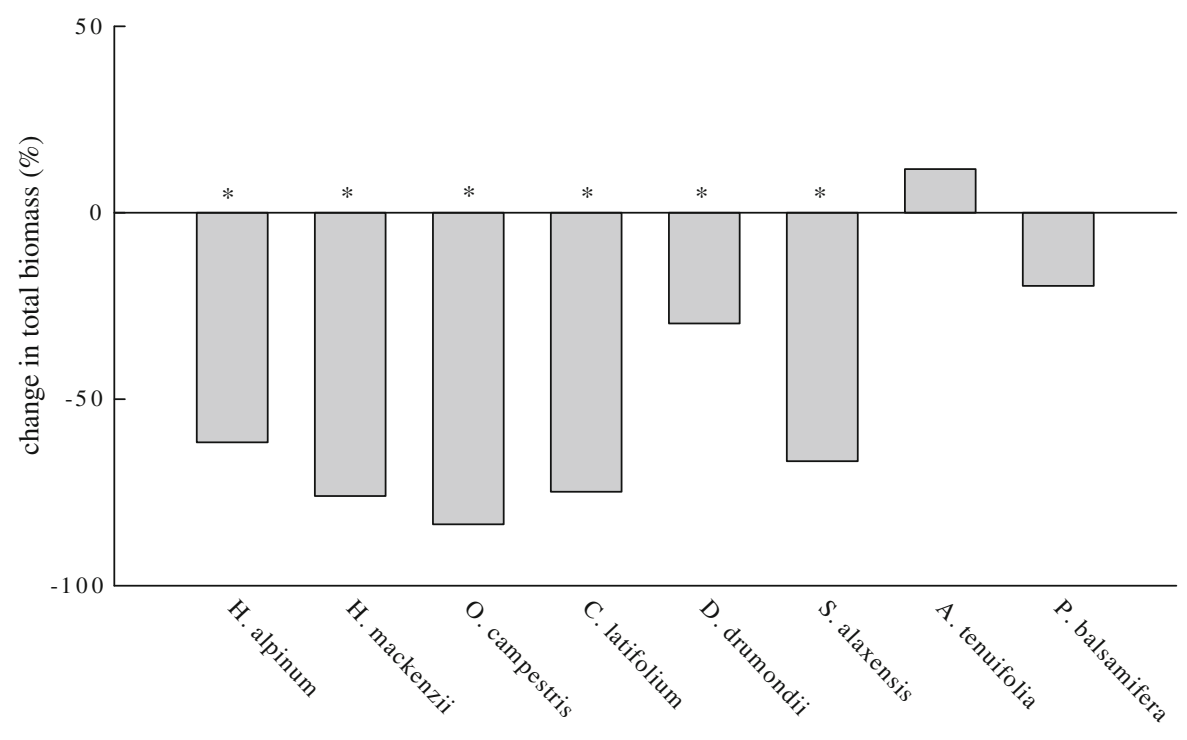

Fig. 3 Relative change in total biomass for species grown under high and low quantities of light. Data are from the control and medium-high shade treatments. An asterisk indicates the treatment means were significantly different $(P<0.05)$. Relative change equation: $[1-(($ medium-high $) /$ control)] $* 100$ 
Fig. 4 Proportion of seedlings that survived being grown under five levels of shading and then over-wintered. Bars indicate standard errors. Different letters indicate treatment means differed significantly $(P<0.05)$

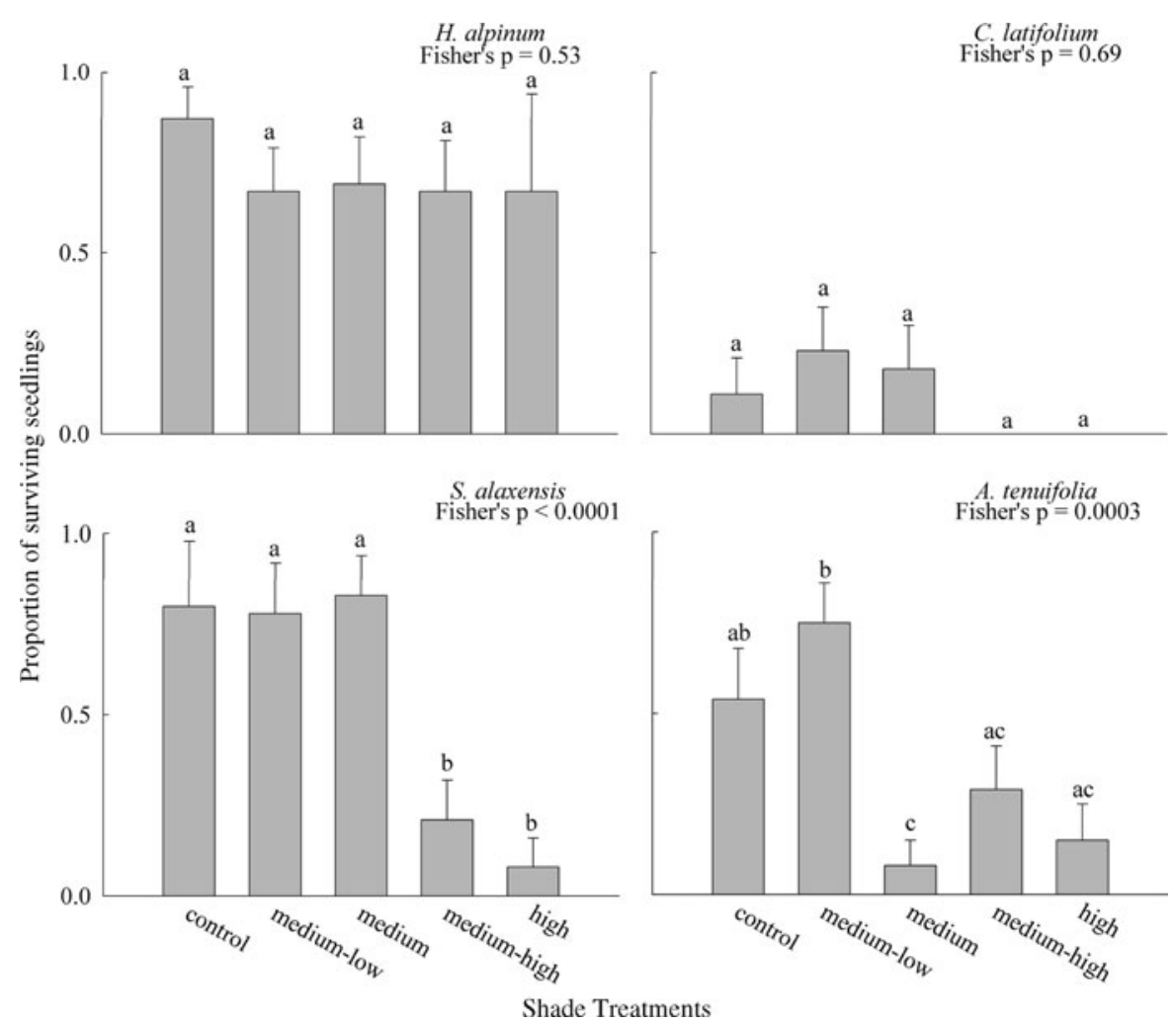

successional floodplain habitats. Sweetclover alters the physical structure of floodplain habitats by shading areas that were previously open to light. Our shading experiment suggests that this novel shade environment can decrease native seedling biomass, which, in turn, can increase over-wintering mortality of common floodplain plant species.

Though we isolated shading, sweetclover may limit native recruitment through competition for several additional resources. Both water and soil nutrients were limited resources at our study sites due to sandy textured soils and low levels of soil nitrogen (Conn et al. 2008a). In Rocky Mountain National Park, Melilotus officinalis and M. alba were shown to decrease soil moisture, phosphorous, and nitrogen during the growing season (Wolf et al. 2004). With as many as 1,307 sweetclover seedlings in our $2 \mathrm{~m}^{2}$ removal plots (Spellman 2008), the rapid growth of so many sweetclover seedlings may reduce soil moisture and nutrients below a threshold that can support native seedlings.

While sweetclover competition was shown to negatively impact recruitment, invasive plants have also been shown to facilitate recruitment (Tecco et al.
2006). Sweetclover is a legume, which can increase soil nitrogen through decomposition of its root and aboveground litter. Therefore, sweetclover may both suppress and facilitate native seedling recruitment. For example, sweetclover shading can stress native plant species during its two-year life cycle and, after mortality, may add nitrogen to soils that could benefit seedling recruitment in the future (sensu del Moral and Bliss 1993; Callaway and Walker 1997) or facilitate the invasion of other non-native plant species (sensu Maron and Conners 1996).

The potential exists that the short-term impacts of sweetclover on native seedling recruitment we observed could have long-term consequences to floodplain biodiversity and community structure. Our findings suggest sweetclover will most impact shade intolerant herbaceous species like Chamerion latifolium, Hedysarum alpinum, Hedysarum mackenzii, and Oxytropis campestris. Sweetclover itself is a ruderal species that is intolerant to shading (Turkington et al. 1978). Without continued disturbance from flooding events, both sweetclover and early successional herbaceous species will be overtopped within 20 years (sensu Viereck et al. 1993; Chapin et al. 2006). Their 
abundances will be greatly reduced as tree and shrub species, such as Salix alaxensis, Alnus incana ssp. tenuifolia and Populus balsamifera, outcompete them for light and other resources (sensu Viereck et al. 1993; Chapin et al. 2006). However, our experiment suggests that under high levels of shading caused by dense patches of sweetclover, all three of these tree and shrub species can have decreased biomass and increased mortality in their seedling stages. Therefore, it is possible that high levels of sweetclover invasion may cause longer-term alterations in floodplain plant communities.

While research has shown high-latitude ecosystems are susceptible to non-native plant introductions (Elven and Elvebakk 1996; Densmore et al. 2001; Rose and Hermanutz 2004; Sumners and Archibold 2007; Carlson et al. 2008), the majority of natural habitats in Alaska do not have non-native plant species (AKEPIC 2010). To preserve the biodiversity and structure of early-successional plant communities, management of sweetclover at road-river interfaces (Wurtz et al. 2006) should be actively pursued now to prevent sweetclover invasion on additional rivers in Alaska.

Acknowledgments We thank Travis Belote, Jeff Conn, John Fox, Christa Mulder, Steve Seefeldt, Dana Thomas, Katie Spellman and two anonymous reviewers for their comments on this manuscript. We thank the University of Alaska Fairbanks Institute of Arctic Biology Greenhouse and the Alaska Plant Material Center for supporting our greenhouse experiment. We thank Heather McIntyre, Mark Winterstein, Gretchen Garcia, Andrea Chin, Rachel Lord, Morgan Skidmore, and Katie Spellman for research assistance. This research was funded by the U.S. Forest Service, Pacific Northwest Research Station, Boreal Ecology Cooperative Research Unit (Fairbanks); Center for Invasive Plant Management; Murie Science and Learning Center; and a University of Alaska Fairbanks Center for Global Change and Arctic Systems Research Award funded by the Cooperative Institute for Arctic Research through cooperative agreement NA17RJ1224 with the National Oceanic and Atmospheric Administration.

\section{References}

Alaska Exotic Plants Information Clearinghouse (2010) Download data from AKEPIC. University of Alaska Anchorage, Alaska Natural Heritage Program. http://akweeds.uaa. alaska.edu. Accessed 2 Nov 2010

Brown RL, Fridley JD (2003) Control of plant species diversity and community invasibility by species immigration: seed richness versus seed density. Oikos 102:15-24
Callaway RM, Walker LR (1997) Competition and facilitation: a synthetic approach to interactions in plant communities. Ecology 78:1958-1965

Carlson ML, Shephard M (2007) The spread of invasive exotic plants in Alaska: is establishment of exotics accelerating? In: Harrington TB, Reichard SH (eds) Meeting the challenge: invasive plants in pacific northwestern ecosystems. USDA Forest Service PNW Research Station, Portland, pp 111-127

Chapin FS III, Walker LR, Fastie CL, Sharman LC (1994) Mechanisms of primary succession following deglaciation at Glacial Bay, Alaska. Ecol Monogr 64:149-175

Chapin FS III, Viereck LA, Adams PC, Van Cleve K, Fastie CL, Ott RA, Mann D, Johnstone JF (2006) Successional processes in the Alaskan boreal forest. In: Chapin FS III, Oswood MW, Van Cleve K, Viereck LA, Verbyla DL (eds) Alaska's changing boreal forest. Oxford University Press, New York, pp 100-120

Chapman WL, Walsh JE (1993) Recent variations of sea ice and air temperature in high latitudes. Bull Am Meteorol Soc 74:33-47

Clark JS, Macklin E, Wood L (1998) Stages and spatial scales of recruitment limitation in southern Appalachian forests. Ecol Monogr 68:213-235

Carlson ML, Lapina IV, Shephard M, Conn, JS, Densmore R, Spencer P, Heys J, Riley J, and Nielsen J (2008) Invasiveness ranking system for non-native plants of Alaska. USDA Forest Service, R10, R10-TP-143, p 218

Conn JS, Beattie KL, Shephard MA, Carlson ML, Lapina I, Hebert M, Gronquist R, Densmore R, Rasy M (2008a) Alaska Melilotus invasions: distribution, origin, and susceptibility of plant communities. Arct Antarct Alp Res 40:298-308

Conn JS, Stockdale CA, Morgan JC (2008b) Characterizing pathways of invasive plant spread to Alaska: I. Propagules from container-grown ornamentals. Invasive Plant Sci Manag 1:331-336

del Moral R, Bliss LC (1993) Mechanisms of primary succession: insights resulting from the eruption of Mount St. Helens. Adv Ecol Res 24:1-66

Densmore RV, McKee PC, Roland C (2001) Exotic plants in Alaskan national park units. U.S. Geological Survey, Alaska Biological Science Center and Denali National Park and Preserve, Anchorage

Elven R, Elvebakk A (1996) Part 1: vascular plants. In: Elvebakk A, Prestrud P (eds) A catalogue of Svalbard plants, fungi, algae, and cyanobacteria. Norsk Polarinstitutt Skrifter 198, Oslo, pp 9-55

Fargione J, Brown CS, Tilman D (2003) Community assembly and invasion: an experimental test of neutral versus niche processes. Proc Natl Acad Sci 100:8916-8920

Foster BL, Tilman D (2003) Seed limitation and the regulation of community structure in oak savannah grassland. J Ecol 91:999-1007

Gordon DR, Rice KJ (2000) Competitive suppression of Quercus douglasii (Fagaceae) seedling emergence and growth. Am J Bot 87:986-994

Hubbell SP, Foster RB, O'Brien ST, Harms KE, Condit R, Wechsler B, Wright SJ, de Lau SL (1999) Light-gap disturbances, recruitment limitation, and tree diversity in a neotropical forest. Science 283:554-557 
Huenneke LF, Thomson JK (1995) Potential interference between a threatened endemic thistle and an invasive nonnative plant. Conserv Biol 9:416-425

Klebesadel LJ (1992) Morphological, physiological, and winterhardiness comparisons among latitudinal ecotypes of biennial sweetclover (Melilotus species) in subarctic Alaska. University of Alaska Fairbanks, School of Agriculture and Land Resources Management Bulletin 91:1-26

Levine JM, Vila M, D'Antonio CM, Dukes JS, Grigulis K, Lavorel S (2003) Mechanisms underlying the impacts of exotic plant invasions. Proc R Soc Lond B Biol Sci 270:775-781

Lipkin R, Murray DF (1997) Alaska rare plant field guide. U.S. Fish and Wildlife Service, National Park Service, Bureau of Land Management, Alaska Natural Heritage Program, and U.S. Forest Service

Mack RN, Simberloff D, Lonsdale WM, Evans H, Clout M, Bazzaz FA (2000) Biotic invasions: causes, epidemiology, global consequences, and control. Ecol Appl 10:689-710

Maron JL, Conners PG (1996) A native nitrogen-fixing shrub facilitates weed invasion. Oecologia 105:302-312

Myneni RB, Keeling CD, Tucker CJ, Asrar G, Nemani RR (1997) Increased plant growth in the northern high latitudes from 1981 to 1991 . Nature 386:698-702

NatureServe (2010) NatureServe Explorer: an online encyclopedia of life, Version 7.1. NatureServe. http://www.nature serve.org. Accessed 10 Nov 2010

Prieur-Richard AH, Lavorel S, Grigulis K, DosSantos A (2000) Plant community diversity and invasibility by exotics: invasion of Mediterranean old field by Conyza bonariensis and Conyza canadensis. Ecol Lett 3:412-422

Reinhart KO, Gurnee J, Tirado R, Callaway RM (2006) Invasion through quantitative effects: intense shade drives native decline and invasive success. Ecol Appl 16:18211831

Rose M, Hermanutz L (2004) Are boreal ecosystems susceptible to alien plant invasions? Evidence from protected areas. Oecologia 139:467-477

SAS Institute, Inc. (1999) SAS Version 9.1. SAS Institute Inc., Cary

Serreze MC, Walsh JE, Chapin FS III, Osterkamp T, Dyurgerov M, Oechel WC, Romanovsky V, Morison J, Zhang T, Barry RG (2000) Observational evidence of recent change in the northern high latitude environment. Clim Change 46:159-207

Spellman BT (2008) The impact of invasive sweetclover (Melilotus alba) in early-successional floodplain habitats of Alaska. Master's Thesis, University of Alaska Fairbanks, Fairbanks, Alaska

Stinson KA, Campbell SA, Powell JR, Wolfe BE, Callaway RM, Thelen GC, Hallett SG, Prati DP, Klironomos JN (2006) Invasive plant suppresses the growth of native tree seedlings by disrupting belowground mutualisms. PLoS Biol 4:727-731

Sumners WH, Archibold OW (2007) Exotic plant species in the southern boreal forest of Saskatchewan. For Ecol Manage 251:156-163

Tecco PA, Gurvich DE, Diaz S, Perez-Harguindeguy N, Cabido M (2006) Positive interaction between invasive plants: the influence of Pyracantha angustifolia on the recruitment of native and exotic woody species. Austral Ecol 31:293-300

Thomas D (2005) Measuring the effects of invasive species on the demography of a rare endemic plant. Biol Invasions 7:615-624

Tilman D (1997) Community invasibility, recruitment limitation, and grassland biodiversity. Ecology 78:81-92

Turkington RA, Cavers PB, Rempel E (1978) The biology of Canadian weeds. 29. Melilotus alba Desr. and M. officinalis (L.) Lam. Can J Plant Sci 58:523-537

Turnbull LA, Crawley MJ, Rees M (2000) Are plant populations seed-limited? A review of seed sowing experiments. Oikos 88:225-238

Turnbull LA, Rahm S, Baudois O, Eichenberger-Glinz S, Wacker L, Schmid B (2005) Experimental invasion by legumes reveals non-random assembly rules in grassland communities. J Ecol 93:1062-1070

Van Cleve K, Viereck LA (1981) Forest succession in relation to nutrient cycling in the boreal forest of Alaska. In: West DC, Shugart HH, Botkin DB (eds) Forest succession concepts and applications. Springer, New York, pp 185-211

Viereck LA, Dyrness CT, Foote MJ (1993) An overview of the vegetation and soils of the floodplain ecosystems of the Tanana River, interior Alaska. Can J For Res 23:889-898

Villano KL (2008) Wildfire burn susceptibility to non-native plant invasions in black spruce forests of interior Alaska. Master's Thesis, University of Alaska Fairbanks, Fairbanks, Alaska

Walker LR, Chapin FS III (1986) Physiological controls over seedling growth in primary succession on an Alaskan floodplain. Ecology 67:1508-1523

Walker LR, Vitousek PM (1991) An invader alters germination and growth of a native dominant tree in Hawaii. Ecology 72:1449-1455

Wolf JJ, Beatty SW, Seastedt TR (2004) Soil characteristics of Rocky Mountain National Park invaded by Melilotus officinalis and M. alba. J Biogeogr 31:415-424

Wurtz TL, Macander M, Spellman BT (2006) Spread of an invasive plant on Alaska's roads and river floodplains: a network model. In: Proceedings of the central Alaska park science symposium, pp 100-103

Yurkonis KA, Meiners SJ, Wachholder BE (2005) Invasion impacts diversity through altered community dynamics. J Ecol 93:1053-1061 